\title{
25. GEOLOGIC CONSTRAINTS ON SUBDUCTION RATES IN THE NANKAI TROUGH ${ }^{1}$
}

\author{
D. E. Karig and C. L. Angevine, Department of Geological Sciences, Cornell University ${ }^{2}$
}

\begin{abstract}
Subduction rates in trenches are more difficult to determine than other types of interplate motion; values are generally deduced from seismologic data and multi-plate kinematic models. Geologic and geometric data have been used, but constraints have been insufficient and the steady-state assumptions that used to be employed are now known to be invalid. Better data from advanced exploration techniques permits a more accurate, shorter-term estimate, based on the geometry of the uppermost trench-fill strata. The width $(w)$ of this slice changes over time $(\delta t)$ at the outer flank by $S_{\mathrm{T}}$ $\operatorname{ctn} \alpha$ and at the inner flank by $D \delta t$, where $D=$ the subduction rate, $S_{\mathrm{T}}=$ sedimentation rate, and $\alpha=$ the dip of the facies boundary between trench fill and basin strata. More generally, $S_{\mathrm{T}}, \alpha$, and $D$ are also time dependent, leading to the more accurate approximation:
\end{abstract}

$$
D=\frac{w(\delta t)-w(0)}{\delta t}+S_{\mathrm{T}} \operatorname{ctn} \alpha-\left(\frac{\mathrm{d} D}{\mathrm{~d} t}+S_{\mathrm{T}} \csc ^{2} \alpha \frac{\mathrm{d} \alpha}{\mathrm{d} t}-\frac{\mathrm{d} S_{\mathrm{T}}}{\mathrm{d} t} \operatorname{ctn} \alpha\right) \mathrm{d} t .
$$

This method, applied to the Nankai Trough, produces an estimate in good agreement with structural and stratigraphic data, but it is somewhat lower than seismologically determined rates.

\section{INTRODUCTION}

One of the more important parameters needed for calculations of deformation related to subduction is the rate of convergence between the descending ocean lithosphere and the arc system. This parameter has generally been determined using a combination of short-term (n $\times 10$ yr.) seismic data and longer-term $\left(\mathrm{n} \times 10^{6}\right.$ yr.) magnetic anomaly data (e.g., Minster and Jordan, 1978), with the implication that plate kinematics are constant over several Ma. Subduction rates, which differ from convergence rates by the rate of accretion or erosion of the inner trench slope, require additional geologic data.

The subduction rate in the Nankai Trough is particularly difficult to determine because the Philippine Plate is surrounded by convergent boundaries. Estimates have varied widely during the past decade or more, in part because different methods have been used, and probably in part because the plate rotational vectors involved have not remained constant during the past few Ma. Reliable subduction and convergence rates during this interval have become important for the location and history of the Philippine-Eurasian pole and for the evolution of the Philippine-Eurasian-Pacific triple junction.

Uplift rates of marine terranes in southwestern Japan, combined with recurrence rates of large earthquakes and interpreted using the elastic rebound theory, led to an early estimate of $8 \pm 4 \mathrm{~cm} / \mathrm{yr}$. (Fitch and Scholz, 1971). The parameters of these large, shallow-focus earthquakes have since led most seismologists (e.g., Kanamori, 1972; Ando, 1975) to suggest seismic slip rates in the central sector of the Nankai Trough of 3.5 to $5 \mathrm{~cm} / \mathrm{yr}$. To these

\footnotetext{
${ }^{1}$ Kagami, H., Karig, D. E., Coulbourn, W. T., et al., Init. Repts. DSDP, 87: Washington (U.S. Govt. Printing Office). 14853.
}

slip rates a component of aseismic slip might be added (Kanamori, 1977). Estimates of convergence rate of the basis on the length of the seismic zone and age of the descending lithosphere range from $13 \mathrm{~cm} / \mathrm{yr}$. (Molnar et al., 1979) to $1.2 \mathrm{~cm} / \mathrm{yr}$. (Shiono, 1982).

Initial deep-sea drilling, on the other hand, suggested a surprisingly low convergence rate of 1 to $2 \mathrm{~cm} / \mathrm{yr}$. This estimate assumed steady-state conditions and balanced sediment influx to the trench wedge with outflow of sediment into the accretionary prism (Karig, Ingle, et al., 1975). More recent syntheses of seismic slip vectors and geologic data used to deduce poles of rotation for the Philippine-Pacific-Eurasian plate system have indicated slip rates in the drilled sector of the Nankai Trough of $4.3 \mathrm{~cm} / \mathrm{yr}$. (Seno, 1977) and $2.5 \mathrm{~cm} / \mathrm{yr}$. (Ranken et al., 1984). The initial discrepancy between estimates based on seismologic and geologic data has been narrowed, but is still a factor of about two. Information derived from DSDP Leg 87 and associated seismic reflection profiling significantly improves the previously available geologic data base and invites a more thorough discussion of the methods by which subduction rates might be determined from geometric and geological data.

\section{METHODS OF SUBDUCTION RATE DETERMINATION}

Determinations of subduction rates using geologic parameters have been relatively crude because the available data provides relatively poor quantitative constraints. However, these constraints can be expected to improve as better seismic profiles, deep-sea drilling results, and data from other advanced exploration techniques become available. Analysis of methodologies used for the determination of subduction rates is treated in some detail here, not only to address the problem in the Nankai Trough but also for future, broader application. 


\section{Hsü and Ryan Method}

The earliest attempt to quantify convergence or subduction rates from geologic and morphologic data was that of Hsü and Ryan (1972) for the Hellenic Trench. They observed the arcward dip of originally horizontal trench turbidites of known age, assumed them to have rotated along a circular arc describing the trajectory of the descending lithosphere, and, with a simple geometric relationship, calculated a linear subduction rate (Fig. 1). This rate is a time-average over the duration since deposition of the stratum used for the calculation.

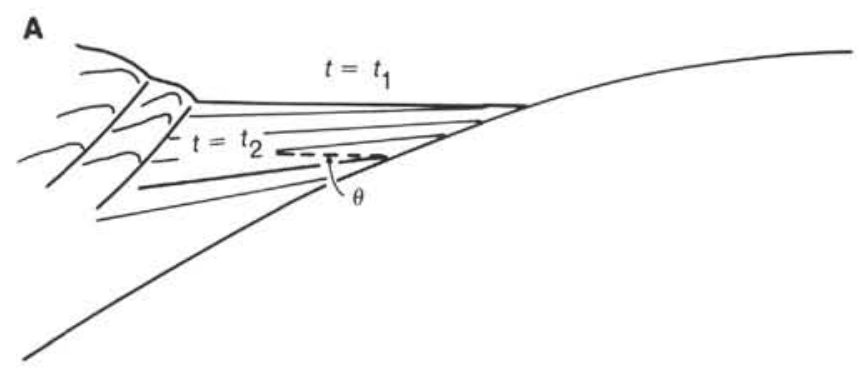

C

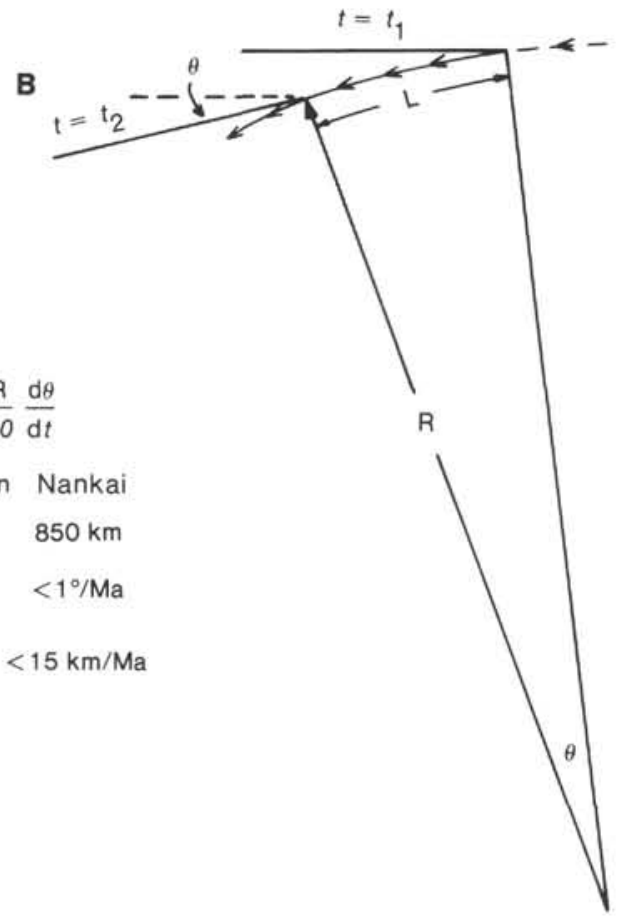

Figure 1. Schematic diagrams illustrating the calculation of subduction rate from the arcward tilting of trench sediments (after Hsü and Ryan, 1972). A. Simplified section of trench wedge showing the downward increase in arcward dip $(\theta)$ of a given stratum with an age $t_{2}$. All strata are assumed to have been deposited as horizontal sheets. Note that the component induced by arcward increase in differential compaction must be removed from the observed dip to obtain the tectonically induced dip. B. Geometric diagram of the relation between the dip acquired by a trench stratum as it rotates with the descending lithosphere through an identical $\operatorname{arcsector}(\theta)$ with radius $\mathrm{R}$. Because $\mathrm{dL}=2 \pi \mathrm{R} / 360 \mathrm{~d} \theta$ where $\theta$ is in degrees, the subduction rate $\mathrm{dL} / \mathrm{d} t$ is determined once the age of the stratum is known. C. Table showing values used to test the procedure in the central Aleutian trench and to apply it in the drilled section of the Nankai Trough. Data from the Aleutian trench are from Scholl and others (1982) and Grow (1982).
Although the descending lithosphere actually displays an arcward increase in curvature (e.g., Karig et al., 1976), the approximation of constant curvature of the short segment of lithosphere in question does not lead to significant error. A more serious problem is defining the mean curvature over a short segment of lithosphere, given local and often large-scale irregularities in the basement topography. This is particularly serious in arcs with wide accretionary prisms, very low outer slope dips, and therefore very large radii of curvature. A large number of long profiles must be averaged (or an initially horizontal basinal stratum must be identifiable) before a general curve can be constructed, from which the local curvature can be estimated.

Another problem in this method concerns differential compaction of the portion of the sediment wedge beneath the horizon used for the calculations. Clearly the outer or oceanward edge of this horizon, beneath which there is much less sediment, will suffer less subsidence than the arcward edge, leading to a greater arcward dip and an overestimation of subduction rate. A typical relationship between porosity and depth $(y)$ (Athy, 1930) is

$$
\phi=\phi_{\mathrm{o}} \exp \left(-\frac{y}{\mathrm{y}_{\mathrm{L}}}\right),
$$

where $\phi=$ porosity, and $\mathrm{y}_{\mathrm{L}}$ is a constant, characteristic of the material. This differential compaction might, under extreme conditions, result in an arcward dip of $1^{\circ}$, but is generally much less and can be estimated with reasonable accuracy.

A further problem is that for residence times of sediment in trenches of less than $1 \mathrm{Ma}$, the dips generated are very small and often difficult to measure. The subduction rate determined by this method also assumes that the load distribution of the descending plate remains constant. Sediment accretion of tectonic erosion affects the position of the deformation front, but changes in the descending plate geometry are buffered by a distributed load distribution on an elastic descending plate and thus can be ignored for the short time period under consideration.

In the Hellenic Trench, Hsü and Ryan (1972) used a global approximation for the radius of curvature averaged over the entire outer slope but obtained a subduction rate consistent with those derived from plate kinematic calculations. We tested the accuracy of this method in the central Aleutian trench, for which the convergence rate appears to be well constrained and for which geometric data are available (Fig. 1). Unfortunately, the sediment fill in this trench has not yet been drilled, and, so far, there are no other trenches where adequate data sets exist.

In the sector of the Aleutian trench near $173^{\circ} \mathrm{W}$, Scholl and others (1982) have carefully measured differential arcward dips of the trench fill as functions of depth and have also provided data from which a radius of curvature can be estimated. Both these data and a long acoustic profile (Grow, 1972) show that R is 550 to $600 \mathrm{~km}$. The orthogonal component of convergence is 
70-73 km/Ma (Minster and Jordan, 1978). A calculated value of $8^{\circ} / \mathrm{Ma}$ for $\mathrm{d} \phi / \mathrm{d} t$, combined with the compaction-corrected differential rates of $\operatorname{dip}(\mathrm{d} \phi / \mathrm{d} z)$, produces an average value of $3 \mathrm{~km} / \mathrm{Ma}$ for $\mathrm{d} z / \mathrm{d} t$. This sedimentation rate is very high, but compares closely with that estimated by Scholl and others (1982) using other criteria.

In the drilled sector of the Nankai Trough, the chronology of trench sedimentation, geometry of the trench wedge, and the curvature of the subjacent lithosphere are now all well constrained. The local radius of curvature of the ocean basement has been determined from a smoothed curve constructed from several depth sections in order to avoid the short-wavelength basement irregularities. The Pliocene turbidite horizon in the Shikoku Basin section served as a more accurate measure of curvature where it could be clearly identified. A measured radius of curvature of $850 \mathrm{~km}$ is somewhat larger than that of the central Aleutian trench, as would be expected from the wider forearc in the Nankai system (Karig et al., 1976).

The internal geometry of the trench wedge in the Nankai Trough is very clearly displayed on the several profiles that were used to construct a composite depth section (Fig. 2). The conclusion that the trench-fill sediments show very little downward increase in landward dip is unavoidable and strongly supports very low late Quaternary rates. Because any systematic tectonically induced dips are too low to be separated from effects of differential compaction, we can only conclude (if this method of calculation is used) that the average rate of subduction over the duration represented by the trench fill $(\sim 1 \mathrm{Ma})$ is less than $2 \mathrm{~cm} / \mathrm{yr}$. (Fig. 1).

\section{Methods Using Trench Wedge Geometry}

A second general method to estimate subduction rates with geologic data uses the geometry of the trench wedge. Helwig and Hall (1974), Moore and coworkers (1975), and others have assumed a steady-state balance between volume influx from sedimentation and outflow from subduction that results in a time-independant geometry of the trench wedge (Fig. 3). Applied to the Nankai Trough after the completion of DSDP Site 298, this method pro- duced a subduction rate of less than $2 \mathrm{~cm} / \mathrm{yr}$. (Karig, Ingle, et al., 1975). More refined rates of trench sedimentation obtained during DSDP Leg 87A and several modifications of the method (e.g., arcward migration of the outer edge of the trench floor) would lead to similar values.

However, the marked decrease in sedimentation rate in the trench wedge that occurred 0.4 to $0.5 \mathrm{Ma}$ ago (site chapter, Site 582, this volume) leads to a reassessment of approaches that assume steady-state conditions and to the realization that deviations from this very stringent condition can produce large errors. For example, subduction could cease entirely, and, as long as a slope beneath the turbidite fill existed, the geometric conditions would remain to permit calculation of the non-zero rate. The search for a more accurate and general method for the determination of subduction rate requires a more complete analysis of the problem.

The trench wedge is bounded on its arcward side by the base of the inner trench slope, or deformation front, and on its oceanward side by a facies change from trenchfill turbidites to basinal pelagics or hemipelagics (Fig. 3). The apical angle of the wedge $(\alpha)$ is the dip of this facies change, which is generally different from the dip of the descending plate $(\theta)$ and not necessarily constant over time. The value of $\alpha$ is related to the sedimentation rate in the trench $\left(S_{\mathrm{T}}\right)$, the hemipelagic sedimentation rate $\left(S_{\mathrm{B}}\right)$, and the dip of the basement $(\theta)$ through the following equation (Fig. 3A):

$$
\tan \alpha=S_{\mathrm{T}} \tan \theta /\left(S_{\mathrm{T}}-S_{\mathrm{B}}\right) .
$$

The behavior of the trench wedge is a function of many variables, four of which, for these calculations, can be assumed to be independent. These four are the convergence rate $(C)$, the rate of influx of sediment to the trench $(I)$, the dip of the descending plate $(\theta)$, and the rate of sedimentation on the ocean plate $\left(S_{\mathrm{B}}\right)$. Not only these variables, but their time-derivatives, must be considered.

Because the information necessary for the determination of most of these parameters is destroyed or obscured

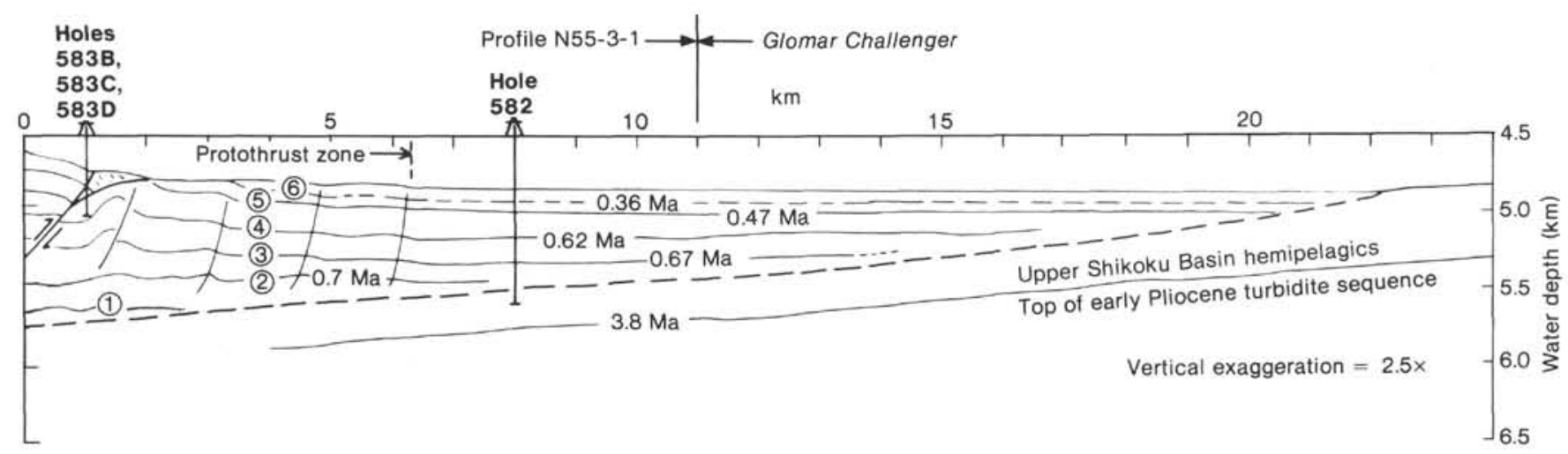

Figure 2. Depth profile of the Nankai Trough through DSDP Site 582, constructed from the reference seismic profile N55-3-1 (Nasu et al., 1982) and from a Glomar Challenger Leg 87 section. Velocities used to convert the Glomar Challenger profile to a depth section were derived from stacking velocities along Profile N55-3-1 and from DSDP Site 297 data (Ingle, Karig, et al., 1975). Key reflectors (circled numbers) are shown with ages determined from drill data at Sites 297 and 582. This composite profile shows the near absence of arcward tilt of trench-fill reflectors as well as the gross geometry of the facies boundary between trench wedge and Shikoku Basin strata. 
A

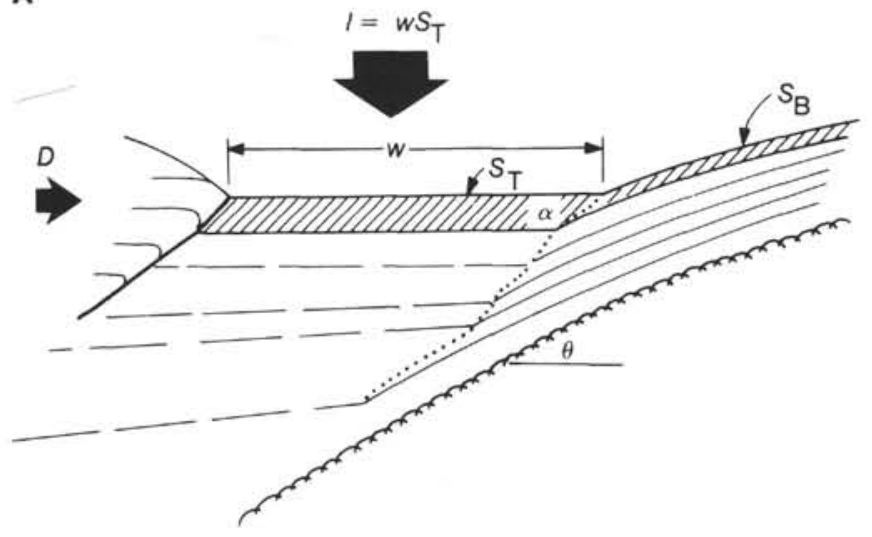

B

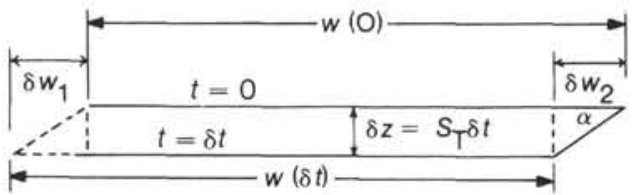

Figure 3. Schematic diagrams of the trench wedge model in which sediment influx $(I)$ is compared with subduction $(D)$. A. Diagram of sediment geometry and definition of some of the functions used in the solution of an "instantaneous" convergence rate discussed in the text. Other of these functions are shown in B (the enlargement of the hachured element of trench fill of part A).

by deformation on the inner slope, analyses of the entire trench wedge have not looked promising. It seems more useful to investigate the slice of trench fill representing the most recent increment of sediment influx to the trench (Fig. 3B). The width of this slice is the width of the trench floor at the time the slice-bounding strata were deposited. This width increases along the outer trench flank by onlap over basinal strata and decreases by migration of the deformation front at the base of the inner slope. This method utilizes the best constrained data and involves the subduction rate $(D)$ through its relationship with the migration of the deformation front. In this approach, $\theta$ and $S_{\mathrm{B}}$ can be assumed to be constant over the duration of the increment without serious loss of accuracy.

Before launching into a mathematical analysis of the problem, we must examine several implicit assumptions and limitations of the method. The most critical variable is $D$, the orthogonal component of the interplate subduction rate. $D$ is assumed to equal the rate at which the deformation front or the base of the inner trench slope advances with respect to any point attached to the descending lithospheric plate. The rate of advance of the deformation front includes the rate of outgrowth by accretion or of retreat by tectonic erosion of the forearc, the magnitude of which generally appears to be $20 \%$ or less of the interplate convergence rate $(C)$.

The assumption that the rate of migration of the deformation front can be so simply related to subduction rate, especially on shorter timescales, requires further justification. It is now recognized that the deformation resulting from subduction is not totally absorbed at the foot of the trench but can be spread across the forearc (e.g., Karig et al., 1980), perhaps variously distributed in different arcs. However, the assumption that the rate of migration of the deformation front equals the subduction rate does not require that all deformation occur at the deformation front, but only that the same fraction of the total shortening occur there over the period under consideration.

Recognition that most of the instantaneous deformation rate is absorbed near the deformation front and that profiles across the basal sections of a single trench slope are quite similar along the trend of the arc suggest that, over the time spans ( $\left.10^{6} \mathrm{yr}.\right)$, this assumption is reasonable. However, the recognition that trench fill is generally accreted as discrete thrust sheets clearly would violate this assumption on the timescale represented by the interval of accretion ( 2 to $4 \times 10^{5} \mathrm{yr}$.).

In the Nankai Trough, the minimum time interval for which this assumption might apply appears to be much shorter $\left(<10^{4} \mathrm{yr}\right.$.) because, in front of the basal thrust, there is a protothrust zone, which serves as the inner boundary of the turbidite plain over which trench sedimentation is active. Strain across the protothrust zone appears to increase linearly arcward (Karig, this volume), suggesting that the deformation front has migrated much more regularly than have the thrusts. Similar zones of incipient deformation have been observed in the Sunda (Karig et al., 1980) and eastern Aleutian arcs (von Huene, 1972). In addition, the individual thrust sheets forming the lower slope of the Nankai accretionary prism are continuous, parallel, and linear for more than $50 \mathrm{~km}$ near the drill sites. This lateral uniformity in mechanical response suggests uniformity across the slope as well. Because the Nankai forearc is accreting, the rate of the basinward migration of the deformation front $(D)$ will be greater than the orthogonal component of the interplate convergence rate $(C)$ by the rate of outbuilding. Without a more complete Neogene history of the southwestern Japan arc, we can only roughly estimate the outgrowth rate, assuming constant progression since the early Miocene when the trench was near Muroto Peninsula on Shikoku (Taira et al., 1982) in a present geographical reference frame. Because there was subsequent shortening within the early Miocene accretionary prism, the original trench position was probably several tens of kilometers further south, leading to an estimate for the rate of outgrowth of between 0.2 and $0.4 \mathrm{~cm} / \mathrm{yr}$.

We determine the subduction rate by considering a thin packet of trench sediments bounded on top and bottom by the isochrons at $t=0$ and $t=\delta t(\delta t>0)$, respectively (Fig. 3). The present day trench floor width is $w(0)$ whereas the paleo-trench floor width is $w(\delta t)$. Of course, the paleo-trench floor has been displaced arcward, where its arcward flank has been deformed and its acoustic definition degraded. Over the time interval in consideration, a thickness, $\delta z$, trench sediment has been deposited; this thickness may be expressed as $S_{\mathrm{T}} \delta t$ where $S_{\mathrm{T}}$ is the observed sedimentation rate in the trench. Trench sediments contact the hemipelagics of the downgoing 
plate along a facies boundary parallel to the trench axis and with a dip $\alpha$.

Past and present-day trench widths are related by

$$
w(\delta t)=w(0)+\delta w_{1}-\delta w_{2} .
$$

We see that $\delta w_{1}$ is the distance that the deformation front has migrated during the time interval so that

$$
\delta w_{1}=D \delta t,
$$

where $D$, the subduction rate, is defined as equivalent to the migration rate of the deformation front. From the geometry of the outer flank of the trench wedge,

$$
\delta w_{2}=S_{\mathrm{T}} \operatorname{ctn} \alpha \delta t .
$$

Equation (2) shows that the subduction rate can be directly determined if the rate of migration of the deformation front can be measured. This is possible for the Nankai section and provides values of between 0.7 and $2.4 \mathrm{~cm} / \mathrm{yr}$. These values are of the same range as those of the more general solution, which must be used if only paleo-trench widths can be estimated. Moreover, the general case is also useful in showing the relationship among the various geologic parameters and in simplifying to the steady-state condition with constant trench width.

Substituting (2) and (3) into (1) yields

$$
w(\delta t)=w(0)+D \delta t-S_{\mathrm{T}} \operatorname{ctn} \alpha \delta t,
$$

which may be solved for the subduction rate when the other quantities are known. Substitution of values derived from DSDP data in the Nankai Trough leads to a value for $D$ near $1 \mathrm{~cm} /$ yr. (Table 1 ).

Equation (4) is strictly valid only when $D, S_{\mathrm{T}}$, and $\alpha$ are constant during the interval $\delta t$. All of these parameters may in fact change with time. We now turn to the derivation of a more general relationship between $w(\delta t)$ and $w(0)$. We assume that $D, S_{\mathrm{T}}$, and $\alpha$ change by $\delta D_{\mathrm{T}}$, $\delta S_{\mathrm{T}}$, and $\delta \alpha$, respectively, over the time interval $\delta t$. If these perturbations are small, $|\delta D / D| \ll 1$ for instance, it is appropriate to let

$$
\begin{gathered}
\delta D=\frac{\mathrm{d} D}{\mathrm{~d} t} \delta t, \\
\delta S_{\mathrm{T}}=\frac{\mathrm{d} S_{\mathrm{T}}}{\mathrm{d} t} \delta t,
\end{gathered}
$$

and

$$
\delta \alpha=\frac{\mathrm{d} \alpha}{\mathrm{d} t} \delta t,
$$

where the derivatives are evaluated at $t=\mathrm{O}$. If the time interval $\delta t$ is large, it may be necessary to include higherorder derivatives in (5). In practice, the higher-order derivatives are likely to be difficult to estimate reliably because of either paucity of data or limits in resolution. To
Table 1. Geometric and geologic parameters in the Nankai Trough.

\begin{tabular}{lccc}
\hline $\begin{array}{c}\delta t[t-t(0)] \\
(\mathrm{Ma})\end{array}$ & $\begin{array}{c}\text { Width } \\
(w \text { in km) })\end{array}$ & $\begin{array}{c}S_{\mathrm{T}}^{\mathrm{a}} \\
(\mathrm{km} / \mathrm{Ma})\end{array}$ & $\begin{array}{c}\alpha \\
(\text { degrees })\end{array}$ \\
\hline 0 & 16.2 & 0.15 & $\sim 4$ \\
0.15 & 17.3 & 0.19 & $2.5<\alpha<4$ \\
0.36 & 18.0 & 0.24 & $2.5<\alpha<4$ \\
0.47 & 20.0 & 0.26 & $2.5<\alpha<4$ \\
0.62 & 23.0 & 0.31 & $2.5<\alpha<4$ \\
\hline
\end{tabular}

Note: See text for further definition of these parameters and values of others.

${ }^{\mathrm{a}} S_{\mathrm{T}}=0.50 t+0.15$.

correct equation (4) for these perturbations, it is necessary to replace the individual parameters in (4) by the sum of the parameter and its perturbation so that

$$
\begin{aligned}
w(\delta t) & =w(0)+[(D+\delta D) \\
& \left.-\left(S_{T}+\delta S_{\mathrm{T}}\right) \operatorname{ctn}(\alpha+\delta \alpha)\right] \delta t .
\end{aligned}
$$

We note that if $|\delta \alpha / \alpha| \ll 1$, then

$$
\operatorname{ctn}(\alpha+\delta \alpha)=\operatorname{ctn} \alpha-\csc ^{2} \alpha \delta \alpha
$$

Substituting (5) and (7) into (6) yields

$$
\begin{aligned}
w(\delta t) & =w(0)+\left(D-S_{\mathrm{T}} \operatorname{ctn} \alpha\right) \delta t \\
& +\left(\frac{\mathrm{d} D}{\mathrm{~d} t}+S_{\mathrm{T}} \csc ^{2} \alpha \frac{d \alpha}{\mathrm{d} t}-\frac{\mathrm{d} S_{\mathrm{T}}}{\mathrm{d} t} \operatorname{ctn} \alpha\right)(\delta t)^{2}
\end{aligned}
$$

where we ignore terms of order $(\delta t)^{3}$ and smaller. Rearranging terms,

$$
\begin{aligned}
D & =\frac{w(\delta t)-w(0)}{\delta t}+S_{\mathrm{T}} \operatorname{ctn} \alpha \\
& -\left(\frac{\mathrm{d} D}{\mathrm{~d} t}+S_{\mathrm{T}} \csc ^{2} \alpha \frac{d \alpha}{\mathrm{d} t}-\frac{\mathrm{d} S_{\mathrm{T}}}{\mathrm{d} t} \operatorname{ctn} \alpha\right) \delta t .
\end{aligned}
$$

To obtain the subduction rate, $D$, the various terms in (9) must be evaluated.

The largest and most critical term in (9) is [ $w(\delta)-$ $w(0)] / \delta t$, the rate of change of the trench width. Near Site 582 the present width of the Nankai Trough is 16.2 $\mathrm{km}$. Paleowidths can be estimated by tracing reflectors of known age from the outer flank of the trench into the protothrust zone, where they lap out against previous deformation fronts. One reflector on the $3.5-\mathrm{kHz}$ profile (Fig. 4), estimated as $0.15 \mathrm{Ma}$ old, and two reflectors 0.36 and $0.47 \mathrm{Ma}$ old on the combined depth section (Fig. 2), give values for $[w(\delta t)-w(0)] / \delta t$ near 7 $\mathrm{km} / \mathrm{Ma}$. The 0.67-Ma reflector, also from the Glomar Challenger section, gives a value of $10 \mathrm{~km} / \mathrm{yr}$., but the inner boundary at this time is much less accurate than the younger data.

The age/depth relationship in the uppermost trenchfill strata, generated from data in DSDP Hole 582 (site 


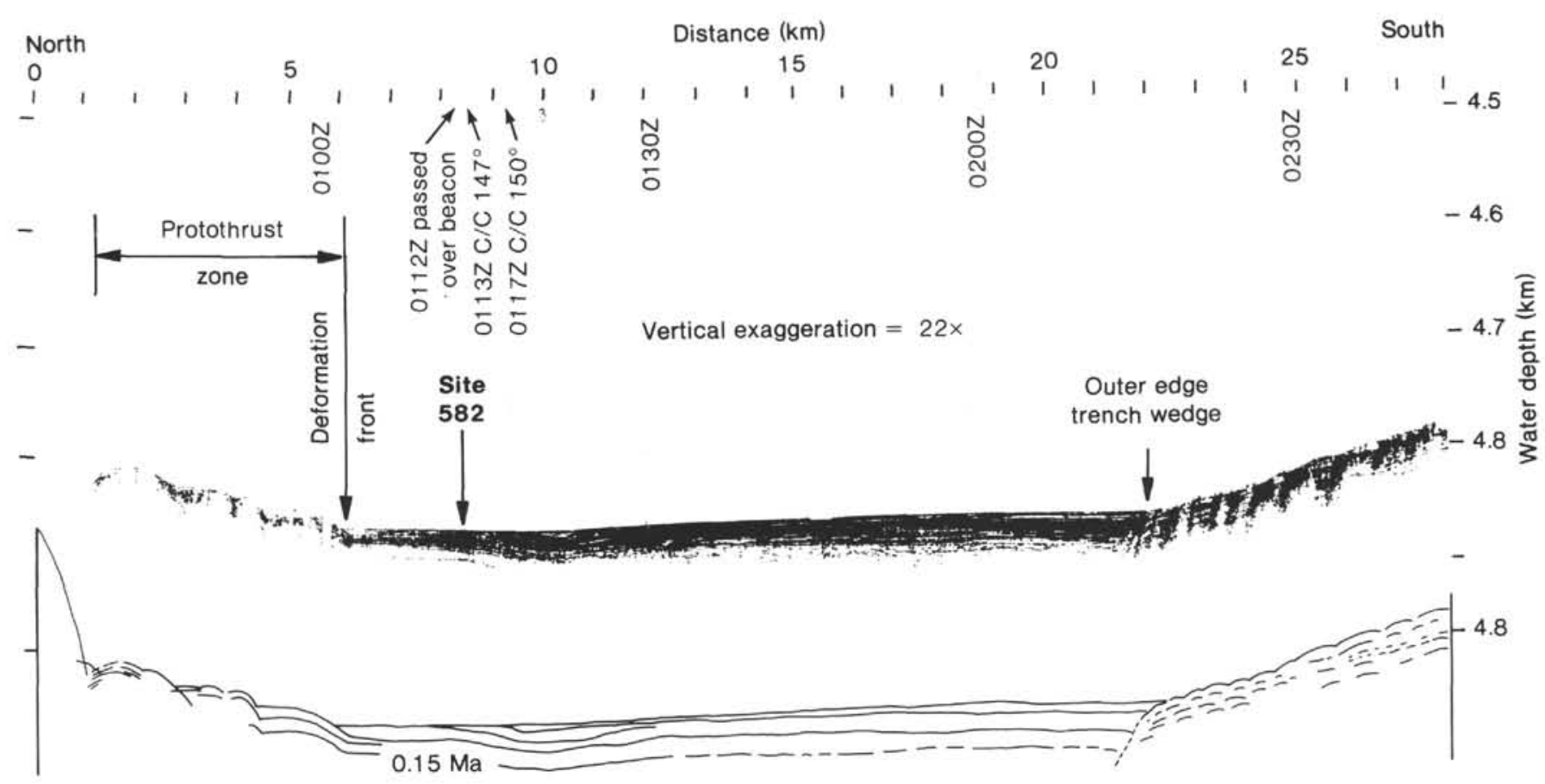

Figure 4. Glomar Challenger $3.5-\mathrm{kHz}$ profile across the Nankai Trough through DSDP Site 582 (top) and interpretive line drawing (bottom) illustrating the pinchout trench turbidites at the deformation front and facies change to hemipelagic strata at the south of the trench floor. Several traced reflectors, including one $0.15 \mathrm{Ma}$ old, show the recent changes in width $(w)$ of the trench floor.

chapter, Site 582 , this volume), can be adequately described by the quadratic equation

$$
z=0.25 t^{2}+0.15 t
$$

where $z$ is in $\mathrm{km}$ and $t$ is in Ma. Differention of (10) once and evaluation at $t=0$ gives a present sedimentation rate $(\mathrm{d} z / \mathrm{d} t)=S_{\mathrm{T}}(0)=0.15 \mathrm{~km} / \mathrm{Ma}$. Differentiation of (10) twice with respect to time gives the time derivative of the sedimentation rate; $\mathrm{d} S_{\mathrm{T}} / \mathrm{d} t=0.50 \mathrm{~km} /$ $\mathrm{Ma}^{2}$.

From the $3.5-\mathrm{kHz}$ profile (Fig. 4) we estimate that, at present, $\alpha=4^{\circ}$. The seismic depth profile (Fig. 2) shows clearly that $\alpha$ decreases with increasing time, so that $\mathrm{d} \alpha$ / $\mathrm{d} t$ is negative. However, $\mathrm{d} \alpha / \mathrm{d} t$ can only be approximated because of the poor seismic control afforded by the Glomar Challenger profile. With an average value for $\alpha$ of $2.6^{\circ}$ at points on the facies boundary representing ages near $0.7 \mathrm{Ma}$ ( $7 \mathrm{~km}$ on Fig. 2), d $\alpha / \mathrm{d} t$ should be 2 to $3^{\circ} /$ Ma.

We have no direct method for evaluating the presentday rate of change of the convergence rate. Because seismologically defined historical convergence rates appear to be higher than the longer-term geologic rates, this derivative should be negative. Its value can at least be limited after the other terms in equation (9) are evaluated.

Substituting values into (9), for $\delta t$ of 0.15 and 0.47 $\mathrm{Ma}$, which represent the age range of measurable paleotrench widths, we find

$$
D=10.4 \mathrm{~km} / \mathrm{Ma} \text { to } 13 \mathrm{~km} / \mathrm{Ma}-\frac{\mathrm{d} D}{\mathrm{~d} t} \delta t \text {. }
$$

Next we suggest that, because convergence rates reflect large-scale mechanical responses of the lithosphere, they vary more smoothly and less rapidly than do $S_{\mathrm{T}}$ and $\alpha$. If so, and if the subduction rate in the Nankai Trough has been increasing for at least the past $1 \mathrm{Ma}, \mathrm{d} D / \mathrm{d} t$ certainly should be less than $50 \mathrm{~km} / \mathrm{Ma}^{2}$. Even this very large value results in a low "recent" subduction rate near $2.0 \mathrm{~cm} / \mathrm{yr}$. and a convergence rate of about $1.7 \mathrm{~cm} / \mathrm{yr}$.

As a formal check of validity of our solution, we find that $\delta S_{\mathrm{T}} / S_{\mathrm{T}}, \delta \alpha / \alpha$, and $\mathrm{d} D / D$ are all 0.5 or less, and that the power series converges reasonably well. Because the functions involved in these calculations probably vary as radically in the Nankai Trough as in any trench, the approach seems generally applicable.

\section{OTHER DETERMINATIONS OF SUBDUCTION RATES IN THE NANKAI TROUGH}

Several corroborative lines of evidence for this low subduction rate can be derived from the thrust relationships outlined at Site 583. Development of the basal thrust, or of the preceding protothrust zone, lifted the trench fill and isolated the upper block, which caused the sedimentation regime there to change. Thus, the boundary between trench fill and slope sediments should provide a maximum age for the passage of the deformation front. At Holes 583, 583F, and 583G this boundary is vague but occurs above, and probably close to, a depth of $90 \mathrm{~m}$, corresponding to an age of about $4.5 \times 10^{5} \mathrm{yr}$. With a distance of $6.0 \mathrm{~km}$ from these holes to the present deformation front, the subduction rate would be between 1.2 and $2.3 \mathrm{~cm} / \mathrm{yr}$. and probably much closer to the lower value. 
The geometry of the basal thrust appears to be characterized by a thrust ramp and hanging-wall anticline (Karig, this volume). The upper corner of this ramp provides another marker of maximum age of displacement and very likely marks the sediment/water interface over which the thrust toe moved. The youngest sediments beneath this upper corner are about $5 \times 10^{5} \mathrm{yr}$. old, suggesting an age for the development of the thrust. Because the basal sheets appear originally to be 6 to $7 \mathrm{~km}$ long (Karig, this volume) and because a new thrust has not yet started at this distance trenchward of the present basal thrust, the deduced subduction rate would again be less than $1.5 \mathrm{~cm} / \mathrm{yr}$.

\section{DISCUSSION AND CONCLUSIONS}

Four apparently independent methods for the determination of subduction rates in the Nankai Trough provide values, averaged over the past $10^{4}$ to $10^{5} \mathrm{yr}$., of between 1.4 and $2.0 \mathrm{~cm} / \mathrm{yr}$. Three of these methods make the critical assumption that rates of subduction migration of the deformation front are equal, but this assumption is strengthened by the similar value obtained using the method of Hsü and Ryan (1972). Included in these values is the rate of outbuilding, probably near $0.3 \mathrm{~cm} /$ yr. The conclusion that the relative rate of convergence between the Philippine Plate and the lower trench slope in the Nankai Trough has been very low for much or most of the Quaternary is difficult to avoid.

If the historic rate of convergence is significantly greater than the longer-term geologic rate that we have determined, an explanation must be sought. Two possibilities are (1) that during the past $10^{5}$ yr. a decreased component of convergence has been absorbed at the base of the inner trench slope, producing an apparent decrease in subduction rate and (2) that there has been a real increase in convergence during the past few $10^{4}$ to $10^{5} \mathrm{yr}$. We have earlier defended our belief that the distribution of convergence has remained constant over the past $1 \mathrm{Ma}$ in the Nankai Trough. Agreement of subduction rate values using this assumption with that obtained from the method of Hsü and Ryan (1972) further supports a real change in subduction rate.

If there has been, as we conclude, a recent increase of the convergence rate between the Philippine and Eurasian plates, this increase might be associated with some early phase in the evolution of a pulse in subduction, but it is even more likely to be an effect of the migration of a relatively nearby pole.

The present pulse of subduction in the Nankai Trough has been estimated to have begun between 2 (Kanamori, 1972) and $4 \mathrm{Ma}$ ago (Seno and Maruyama, 1984). The latter estimate is based largely on the age of the top of a turbidite sequence that underlies the Nankai Trough fill and extends southward into the Shikoku Basin, well beyond DSDP Site 297, where it was estimated to be early Pliocene in age (Karig, Ingle, et al., 1975). Karig, Ingle, and others (1975) interpreted this event as marking the initiation of the trough as a sediment trap, but Seno and Maruyama (1984) favor the more restrictive interpretation that it marks the beginning of a subduction pulse. However, subduction along the Philippine sector of this plate boundary has been active for at least $5 \mathrm{Ma}$ and very probably for more than $10 \mathrm{Ma}$ (Karig, 1983; Hayes and Lewis, 1984). For this reason we favor the previous interpretation (Karig, Ingle, et al., 1975) that subduction was occurring before and during basinal turbidite deposition southwest of Japan, but at a local rate so slow that high sediment-influx rates to the trench led to filling and overflow into the Shikoku Basin. A mid-Miocene (13-15 Ma) initiation of subduction along the Nankai Trough is supported by the existence of a high-velocity, aseismic extension to the descending lithosphere beneath southwestern Japan (Hirahara, 1981) and by the $13 \mathrm{Ma}$ age of the boninitic Setouchi volcanic belt, which is presumed to be associated with this subduction pulse (Tatsumi, 1982).

Rapid subduction along this plate boundary in the Philippine Archipelago, contemporaneous with very slow subduction in the Nankai Trough, would require the Eurasian-Philippine pole for much of the present subduction pulse to have been much closer to the Nankai Trough than it is at present. The apparent middle Quaternary increase in convergence between the Izu arc and Honshu (Matsuda, 1978; Nakamura et al., in press) suggests that this earlier pole lay very close to the Philippine-EurasianPacific triple junction and that, over the past 1-2 Ma, it has been migrating northeastward towards a present position near $37^{\circ} \mathrm{N}, 141^{\circ} \mathrm{E}$ (Ranken et al., 1984). The complex and rapidly changing geology in the Nankai Trough and triple junction area thus very likely does not reflect sudden large changes in position and/or rates of rotation of plate poles, but rather it results from large changes in linear slip rates along sections of the plate boundary close to a pole that was undergoing relatively minor changes in position and, probably, very little change in rate of rotation.

\section{REFERENCES}

Ando, M., 1975. Source mechanisms and tectonic significance of historical earthquake along the Nankai Trough, Japan. Tectonophysics, 27:119-140.

Athy, L. F., 1930. Density, porosity and compaction of sedimentary rocks. Am. Assoc. Pet. Geol. Bull., 14:25-35.

Fitch, T. J., and Scholz, C. H., 1971. Mechanism of underthrusting in southwest Japan: a model of convergent plate interactions. J. Geophys. Res., 76:7260-7292.

Grow, J. A., 1972. A geophysical study of the central Aleutian arc [Ph. D. dissert.]. University of California, San Diego.

Hayes, D. E., and Lewis, S. D., 1984. A geophysical study of the Manila Trench, Luzon, Philippine. 1, Crustal structure, gravity, and regional tectonic evolution. J. Geophys, Res., 89:9171-9195.

Helwig, J., and Hall, G. A., 1974. Steady-state trenches? Geology, 309-316.

Hirahara, K., 1981. Three-dimensional seismic structures beneath southwest Japan: the subducting Philippine Sea plate. Tectonophysics, 79:1-44.

Hsü, K. J., and Ryan, W. B. F., 1972. Summary of the evidence for extensional and compressional tectonics in the Mediterranean. In Ryan, W. B. F., Hsü, K. J., et al., Init. Repts. DSDP, 13, Pt. 2: Washington, D.C. (U.S. Govt. Printing Office), 1011-1019.

Ingle, J. C., Jr., Karig, D. E., and Shipboard Scientific Party, 1975. Site 297. In Karig, D. E., Ingle, J. C., Jr., et al.. Init. Repts. DSDP, 31: Washington (U.S. Govt. Printing Office), 275-316.

Kanamori, H., 1972. Tectonic implications of the 1944 Tonankai and 1946 Nankaido earthquakes. Phys. Earth Planet. Inter., 5:129-139. 1977. Seismic and aseismic slip along subduction zones and their tectonic implications. In Talwani, M., and Pitman, W. C., III 
(Eds.), Island Arcs, Deep Sea Trenches and Back-Arc Basins: Washington (Am. Geophys. Union), Maurice Ewing Series, 1:163-174.

Karig, D. E., 1983. Accreted terranes in the northern part of the Philippine Archipelago. Tectonics, 2:211-236.

Karig, D. E., Ingle, J. C., Jr., et al., 1975. Init. Repts. DSDP, 31: Washington (U.S. Govt. Printing Office).

Karig, D. E., Caldwell, J. G., and Parmentier, E. M., 1976. Effects of accretion on the geometry of the descending lithosphere. J. Geophys. Res., 81:6281-6291.

Karig, D. E., Moore, G. F., Curray, J. R., and Lawrence, M. B., 1980. Morphology and shallow structure of the lower trench slope off Nias Island, Indonesia. In Hayes, D. E. (Ed.), Tectonic and Geological Evolution of Southeast Asian Seas and Islands: Washington (Am. Geophys. Union), Geophysical Monograph 23:179-203.

Matsuda, T., 1978. Collision of the Isu-Bonin arc with central Honshu: Cenozoic tectonics of the Fossa Magna, Japan. J. Phys. Earth, 26(Suppl.):409-421.

Minster, J. B., and Jordan, T. H., 1978. Present-day plate motions. J. Geophys. Res., 83:5331-5354.

Molnar, P., Freedman, D., and Shih, J. S. F., 1979. Lengths of the intermediate and deep seismic zones and temperatures in downgoing slabs of lithosphere. Geophys. J. R. Astron. Soc., 56:41-54.

Moore, G. F., Caldwell, J. G., and Karig, D. E., 1975. Steady-state trenches? (Comment). Geology, 3:221-222.

Nakamura, D., Kunihiko, S., and Yonekura, N., in press. Subduction, bending, and eduction-present and Quaternary tectonics of the northern border of the Philippine Sea plate. Bull. Soc. Geol. Fr.

Nasu, N., et al., 1982. Multi-channel Seismic Reflection Data Across Nankai Trough: Tokyo (Ocean Research Institute, University of Tokyo), IPOD-Japan Basic Data Series, No. 4.
Ranken, B., Cardwell, R. K., and Karig, D. E., 1984. Kinematics of the Philippine Sea plate. Tectonics, 3:555-576.

Scholl, D. W., Vallier, T. L., and Stevenson, A. J., 1982. Sedimentation and deformation in the Amlia Fracture Zone sector of the Aleutian Trench. Mar. Geol., 4:105-134.

Seno, T., 1977. The instantaneous rotation vector of the Philippine Sea plate relative to the Eurasian plate. Tectonophysics, 42:209-226.

Seno, T., and Maruyama, S., 1984. Paleogeographic reconstruction and origin of the Philippine Sea. Tectonophysics, 102:53-84.

Shiono, K., 1982. Frontal shape of the seismic slab by normal subduction of a dead spreading axis and a preliminary application to southwest Japan. J. Geosci. Osaka City Univ., 25:19-33.

Taira, A., Okada, H., Whitaker, J. H., and Smith, A. J., 1982. The Shimanto belt of Japan: Cretaceous-lower Miocene active-marign sedimentation. In Leggett, J. K. (Ed.), Trench and Forearc Geology: Sedimentation and Tectonics on Modern and Ancient Active Plate Margins: London (Geol. Soc. London), Spec. Publ. 10:5-26.

Tatsumi, Y., 1982. Origin of high-magnesian andesites in the Setouchi volcanic belt, southwest Japan. II. Melting phase relations at high pressures. Earth Planet. Sci. Lett., 60:305-317.

von Huene, R., 1972. Structure of the continental margin and tectonism at the eastern Aleutian Trench: Geol. Soc. Am. Bull., 83: 3613-3626.

Date of Initial Receipt: 22 October 1984 Date of Acceptance: 2 November 1984 